\title{
Policy Direction for AHP-Based Community Nutrition Management Post Eruption of Dempo Volcano, Pagar Alam City - Indonesia
}

\author{
Yessy Aprihatin, Dedi Hermon, Eri Barlian, Indang Dewata, Iswandi Umar
}

\begin{abstract}
The research aims to produce a model of the post-disaster response policy for the volcano eruptions in Pagar Alam City, South Sumatera province. These policy directions are obtained using data collected through interviews and Focus Group Discussion (FGD). Subsequently analyzed using Analytical Hierarchy Process (AHP). In drafting a nutritional response policy direction there are three criteria are consisting of human resources, food, and policy. From these criteria, eight alternative policies are resulting in a hierarchy of policy directions with sequential priorities as follows: Food distribution is done on time, transparent and safe, humane and by local conditions; Strict supervision of the communal kitchen; Professionalism of field energy for the handling of refugee nutrition; Improved cross-program coordination and sectoral; Food maintenance with disaster emergencies; Community empowerment of nutritional response; Ready-made fund allocation for basic needs; and monitoring and evaluation of the nutritional status of refugees. All three priorities with the implementation strategy can be used as a solution in the response to the Community nutrition disaster victims, especially in vulnerable groups i.e: infants, toddlers, children, pregnant women, nursing mothers, and the elderly.
\end{abstract}

Keywords: Nutrition, volcano dempo, policy, pagar alam.

\section{INTRODUCTION}

Geographically, Indonesia is a country located in the equator, located between the continent of Asia and Australia as well as by the Pacific Ocean and the Indies. Besides, Indonesia is also located at the confluence of three major world tectonic plates. In addition to natural disasters, Indonesia also has a very complex social disaster, due to large population with uneven spread, unordered spatial arrangement, deviation of natural wealth utilization, the influence of globalization and other social problems, thus

Revised Manuscript Received on May 15, 2020.

* Correspondence Author

Yessy Aprihatin*, his/her Program of Diploma III Nursing and doctoral program of environmental science, Universitas Negeri Padang, Padang, Indonesia. Email: yessyaprihatin@fik.unp.ac.id

Dedi Hermon, Department of geography and doctoral program of environmental science, Universitas Negeri Padang, Padang, Indonesia. Email: dihermon006@gmail.com

Eri Barlian, Department of doctoral program of environmental science, Universitas Negeri Padang, Padang, Indonesia. Email: eribarlian@unp.ac.id

Indang Dewata, Department of doctoral program of environmental science, Universitas Negeri Padang, Padang, Indonesia. Email: indangdewata@fmipa.unp.ac.id

Iswandi Umar, Department of geography and doctoral program of environmental science, Universitas Negeri Padang, Padang, Indonesia. Email: iswandi_u@yahoo.com

(c) The Authors. Published by Blue Eyes Intelligence Engineering and Sciences Publication (BEIESP). This is an open access article under the CC BY-NC-ND license (http://creativecommons.org/licenses/by-nc-nd/4.0/) making Indonesia as a country that is very vulnerable to disaster, both natural disasters and caused by humans [1-5].

Indonesia has 127 active volcanoes spread across Sumatra, Java, Bali, Nusa Tenggara, Banda, Halmahera, and North Sulawesi [6]. One of the active volcanoes in Sumatra is Volcano Dempo. Mount Dempo is located in Pagar Alam City, South Sumatra province with a height of 3159 MASL, and has 2 peaks with an active mountain status that has suffered an eruption of 19 times since 1818 until the year 1974 [7].

The eruption character of Volcano Dempo is a phreatic eruption of the crater lake accompanied by a flood of mud/lava eruptions and rain ash. Every time it erupts both small and large, Volcano Dempo always spewed rocks and thick mud. Since the eruption of Merapi volcano in 2010, it makes Volcano Dempo again doing its activities, but with normal status. However, the threat of eruptions or eruptions on Mount Dempo can be at any time [8].

If Volcano Dempo has an eruption, it can be ensured that people who are around the mountain area should evacuate to a safe place. Within a certain period or by the condition of being safe, refugees will remain in shelters such as emergency tents, mosques or government-designated places/locations. Consequently, the health crisis will occur because of the many people who gather or evacuate in one place, the problem of sanitation, the difficulties of clean water, inadequate nutrients, the occurrence of movement of the disease due to changes in the post-disaster environment, or due to the displacement of the population due to displaced. Besides, the traumatic consequences of disasters are also a health crisis that can result in people/victims of stress disaster even psychiatric disorders [9]. However, the health crisis that often becomes a problem in IDP camps is the nutritional community/disaster victims who live in evacuation sites are often neglected. Insufficient food supplies will have an impact on the long-term decline in health and directly influence the level of fulfilment of nutritional needs. However, nutritional problems do not arise immediately after the disaster. But if there is no good countermeasure, then this problem will have enormous potential to occur, especially will be felt worse by the vulnerable population group [10]. As mentioned in article 55 (2) ACT No. 24 of the year 2007 on disaster relief, vulnerable groups include a). Infants, toddlers and, children; b). Mothers who are pregnant or breastfeeding; c). Disabled; and d) elderly people. In addition to the four groups of people, in the regulation of BNPB head number, 7 the year 2008 about the basic requirements of the procedure for fulfilling the needs of the sick are added as part of vulnerable groups in disaster conditions [5]. 
In a disaster relief effort, the overthrow of the health crisis especially nutrition still facing various obstacles, among others: information systems and coordination mechanisms that have not been well, mobilization of assistance to the location of the disaster is still hindered, and financing systems that do not support. These constraints cause the relief optimal, so the disaster health crisis can not be repeated as early as possible [11-12]. Facing the problem above, it is necessary how to prevent disaster in the health of public nutrition/disaster victims, which must be prepared and implemented when the disaster itself has not occurred. Stakeholders must adapt to the perspective of a disaster management system that disasters are part of a development program or public service that must be implemented regularly, covering all aspects of disaster risk reduction, not only in the event of disaster emergencies, including disaster relief. Therefore, it is necessary to be drafted in the form of policy direction as the appropriate mitigation measures in the disaster prevention or eruption of volcano Dempo in the health sector is a nutritional response to the community/disaster victims, so that post-disaster eruptions, problems of health crisis especially nutrition can be solved quickly, precisely, and effectively. The research aims to produce a model of the post-disaster response policy for the volcano eruptions in Pagar Alam City, South Sumatera province.

\section{RESEARCH METHODOLOGY}

This research is a qualitative study conducted in 3 phases. The first stage, interviewed with the community around lecturer of nutrition Department of Kemenkes Poltekkes municipal health office, and the Regional Disaster Management Agency about the impact of volcano Dempo eruption and the solutions needed for the community when evacuating to remain adequate nutrients. Furthermore, the determination of criteria and alternative policies are compiled from the results of interviews and literature studies. At stage three, FGD is carried out with experts in the field of nutrition and disaster eruption or volcano eruption. The results of the FGD, analyzed by the method of AHP using the Software Expert Choice 11. AHP is a method to make an alternative ranking decision in choosing one of the best when the decision-maker and has a variety of criteria. The criteria and the alternative are comparative judgment using the scale of comparison in pairs (pairwise) [4-13].

Table-I: Banding Scale in Pairs

\begin{tabular}{cl}
\hline & \\
\hline Value & Description \\
3 & Equally important \\
5 & Somewhat more important one over other \\
7 & Quite important \\
9 & Extreme important \\
$2,4,6,8$ & The Middle value between two adjacent decisions \\
\hline
\end{tabular}

Source [4-13]

\section{REVIEW CRITERIA}

According to the Department of Mining and Energy, General Mining Directorate, Directorate of Volcanology, in the year 1974 occurred volcano Dempo eruption that caused the sulfur rain almost all parts of Pagar Alam City. Around to disaster victims especially infants and toddlers are not Volcano Dempo, the city government of Pagar Alam City, Palembang, the social service, Department of Food Security,

Volcano Dempo, There are several areas of settlements (rural) that belong to the area prone/alert with a radius of 8 $\mathrm{Km}$ from the youngest crater, including the location of the government office of Pagar Alam City which is included in danger area if there is an eruption [14]. In addition to the sulfur rain, the danger of Eflata also occurs which is estimated to include areas outside the danger area that are almost circular with a radius of $8 \mathrm{~km}$, and the centre is in the middle of the crater. These hazards include lava flows, hot clouds, and lava and broaden following the river valley, northwards and northwest. The lava flows and the hot lava through two rivers i.e the Betung River and the Batunipis River, which flows through residential areas, such as Tanjung Aro, Pematang Bango, Beringin Jaya, Tanjung Mirror, Tanjung Payang, Pagar Agung, to the furthest point at a radius of $15 \mathrm{Km}$ from the youngest crater. Areas of danger based on the spread of volcanic bombs and other flats that are vomited directly from the eruption point, covering the area of a circle-shaped finger-model policy of nutrition countermeasures post-disaster eruption Volcano Pagar Alam City, South Sumatra province, the radius of $5 \mathrm{~km}$ centred in the middle of the youngest crater, where on this radius there are tea plantations and parts of protected forest.

Based on the above results, it is known if there is an explosion or eruption of Volcano Dempo again, it is most likely that many people are displaced and become the beginning of nutritional problems. The problem of post-disaster nutrition begins with insufficient food supply in a certain period so that there is a decrease in the degree of health in the long term will directly affect the level of fulfilment of the nutritional needs of disaster victims.

This condition can certainly cause worse impacts when not handled immediately. Thus, local governments that have been authorized by the central government must be fast, responsive and effective in addressing the problem. There is a model of public nutrition response policy post-disaster eruptions or volcano-generated eruptions, hopefully, it can be considered and a solution for local government.

Based on the results of interviews, FGD that have been conducted, obtained potentials of nutritional problems that will occur if Volcano Dempo has an eruption, as follows:

1. The number of people who evacuate or become disaster victims will be difficult in the data because sometimes information received from public leaders or local leaders are not valid.

2. In food aid distribution, certain parties appear to take advantage of the circumstances by taking advantage of the food aid provided, so that there is a buildup of aid in one area, while other areas are experiencing deficiencies because the data provided is not by the actual circumstances.

3. Food aid that comes from inside and outside the country, tends to be close to the expiration period, sometimes even through expiry times, even when arriving at a place of refuge in the condition has been decaying. The situation makes some donors disappointed and prefer to channel the goods directly to the nearest location. 
Such conditions cause the scrolling of the aid to be lame and uneven.

4. Nutritional problems tend to occur in vulnerable groups, infants, toddlers, pregnant mothers and composing and elderly, requiring special nutritional treatment.

5. The inability of kitchen officers to prepare infants and toddlers, escort food for breast milk (MP-ASI), snack foods for infants and toddlers.

From these results, can be inferred in post-disaster nutritional problems in case of volcano eruptions or eruption is very vulnerable to infants, toddlers and elderly. This follows with the information of World Health Organization (WHO) that the greatest death occurred in the age group 0-6 months. If this nutrient problem does not get adequate attention at the time of evacuation, not impossible infants and toddlers will experience malnutrition, which then continues to be a bad nutrient that can be a generation of very low intelligence and The Lost Generation [15].

Furthermore, the elderly have a synergistic interaction between nutrition due to reduced food consumption due to lack of appetite, decreased nutrient impairment, diarrhoea and increased due to physiological status [16]. In addition to physiological status, mental conditions also greatly affect elderly nutritional intake. According to [17], the mental condition is very related to elderly nutritional intake. Prolonged stress can enlarge both physical and mental illness and do not close the possibility that the elderly will experience a breakup that eventually leads to depression [17]. Therefore, adequate nutritional needs are essential for the elderly through the empowerment of nutrient-consuming food [18].

Activities in the handling of nutrients in the emergency include several activities such as nutritional services, nutritional counselling, special energy or human resources in the field of nutrition, and food provision [18]. Nutritional services are carried out by a nutrient that is placed specifically the place of evacuation to prepare emergency food, nutrition counselling activities aims to change the behaviour and build mental refugees to maintain and improve the status of Nutrition, and nutritionists are expected to give attention to the cleanliness and a food menu that will be provided including the preparation of foodstuffs should be in the shortest time possible to meet the nutritional needs of refugees. Therefore, nutrition response, especially to infants, toddlers, and elderly in disaster situations, is important to be done quickly, precisely and effectively.

In drafting the policy direction, determined the basic criteria or indicators that become the main points to be considered in the distribution of nutrition. Dai interviews, FGD and literary studies are in 3 criteria, i.e human resources, foodstuffs, and policy. Furthermore, from these criteria, the alternative policies are compiled as follows:

1. Empowering The Nutrition Response community

2. Strict supervision of the communal kitchen in evacuation

3. The Professionalism of field energy for the handling of refugee nutrition

4. Ready-made funds allocation to fulfil basic needs

5. Food Maintenance with disaster emergencies [19-22]

6. Food delivery is done on time, transparent, safe and humane

7. Improved cross-program coordination and sectoral

8. Monitoring and evaluation of the nutritional status of refugees.

Three criteria and eight alternative policies, processed using the technique of AHP, where the model hierarchy of nutritional countermeasures post-disaster eruption of Volcano Dempo in Pagar Alam City, South Sumatera Province Can be seen in Fig. 1. The figure shows that the purpose of the policy relates to each criterion and each criterion relates to the entire alternative policy.

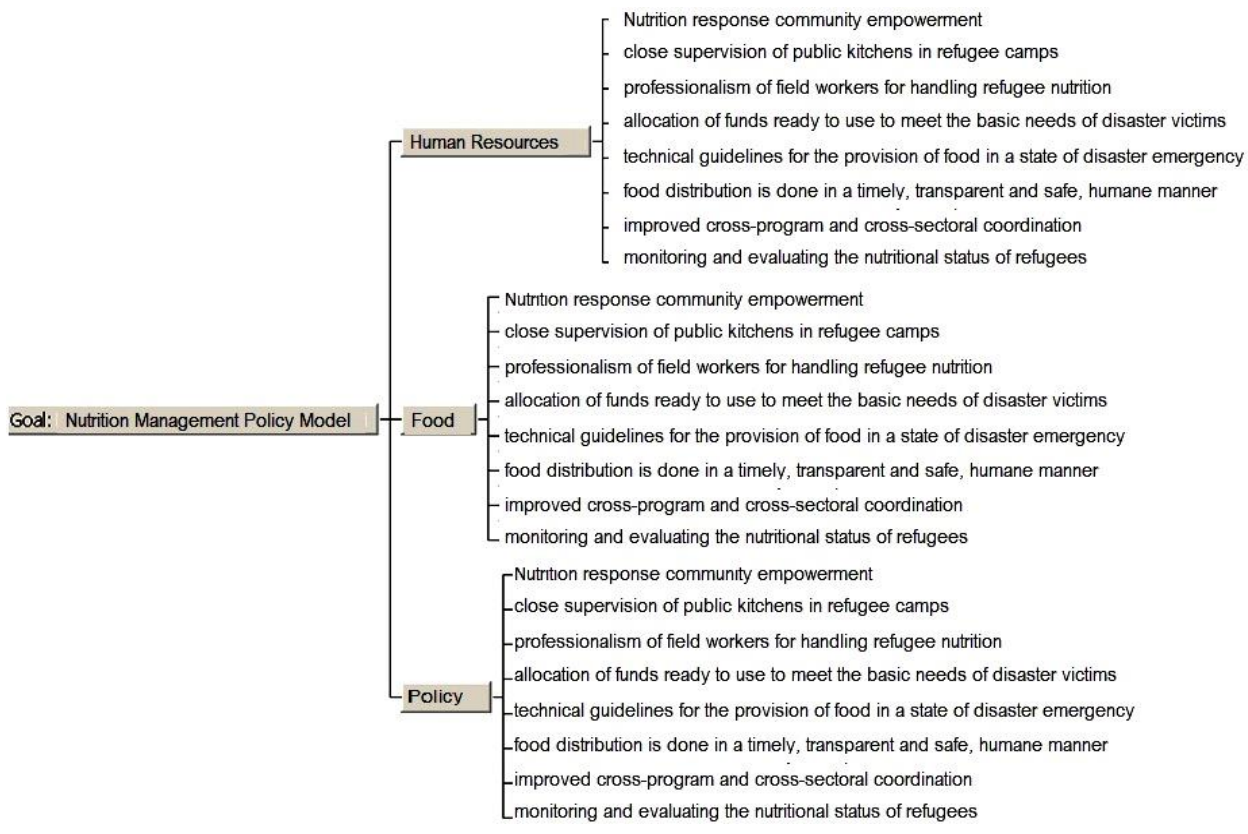

Fig. 1. Policy hierarchy

Published By:

Blue Eyes Intelligence Engineering

\& Sciences Publication

8 (C) Copyright: All rights reserved.

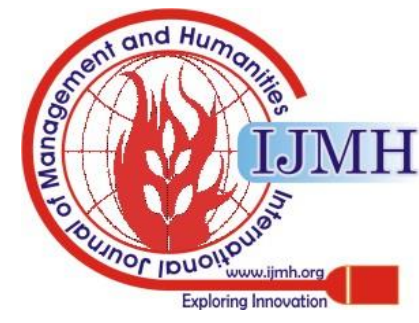


The result of processing using expert choice obtained weights from the level of importance at the criteria level and the alternate level of policy. Fig. 2 shows the weight of the importance between criteria that if sorted by high weight to low acquired human resources, food, and obstetrical. This means that in drafting the policy of nutritional countermeasures, the field problems can be addressed if the human resource is more focused and improved health workers. Next, the policy direction has a consistency value of $<0.1$ i.e. 0.04 which describes the given weight consistently in setting the scale comparison of a pair of criteria, so that the resulting solution is beneficial for the user.

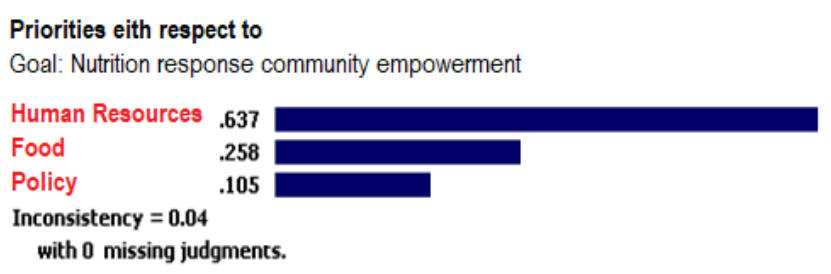

Fig. 2. Weight of Interest Between Criteria and Consistency Policy

From the results of the analysis in pairs for alternative policies, obtained policy priorities, in the order of which: food distribution is done on time, transparent and safe, humane and following with local conditions; Strict supervision of the communal kitchen; Professionalism of field energy for the handling of refugee nutrition; Improved cross-program coordination and sectoral; Food maintenance with disaster emergencies; Community empowerment of nutritional response; Ready-made fund allocation for basic needs; and monitoring and evaluation of the nutritional status of refugees that can be seen in Fig. 3 .

$5.9 \%$ Nutrition response community empowerment
$21.4 \%$ close supervision of public kitchens in refugee camps
$14.5 \%$ professionalism of field workers for handling refugee nutrition
$3.1 \%$ allocation of funds ready to use to meet the basic needs of disaster victims
$6.5 \%$ technical guidelines for the provision of food in a state of disaster emergency
$37.5 \%$ food distribution is done in a timelv. transparent and safe. humane manner
$8.1 \%$ improved cross-program and cross-sectoral coordination
$3.0 \%$ monitoring and evaluating the nutritional status ot retugees

Fig. 3. Policy Priorities

The policy direction for Community Nutrition management in Pagar Alam City post-disaster eruption of Volcano Dempo prioritized on 3 policies that can be implemented with the following strategies:

1. Distribution of food is done on time, transparent and safe, humane and following with local conditions

2. Strict supervision of the common kitchen

3. The Professionalism of field energy for the handling of refugee nutrition

All three priorities with the implementation strategy can be used as a solution in the response to the Community nutrition disaster victims, especially in vulnerable groups i.e: infants, toddlers, children, pregnant women, nursing mothers, and the elderly. This nutritional response was also done together with the social service, PMI and the commander of the Military Regional Command related to the provision of a communal kitchen and the provincial food security Service regarding the rapid support of the basic needs of refugees (rice). Thus, the maintenance of food performed in the event of a disaster can fulfil food and nutrition needs effectively.

\section{CONCLUSION}

Volcano Dempo is an active mountain located in Pagar Alam City that has been erupted and can be ensured in the event of an eruption, the people who are around the mountain area must evacuate to a safe place or shelter. One of the most common crises in the evacuation is the health crisis, especially the problem of public nutrition/disaster victims that are often neglected. This Model of community nutrition countermeasures post-disaster eruption of Volcano Dempo is one of the solutions. The policy direction has three criteria and eight alternative policies with sequential priorities as follows: Food delivery is done on time, transparent and safe, humane and following with local conditions; Strict supervision of the communal kitchen; Professionalism of field energy for the handling of refugee nutrition; Improved cross-program coordination and sectoral; Food maintenance with disaster emergencies; Community empowerment of nutritional response; Ready-made fund allocation for basic needs; and monitoring and evaluation of the nutritional status of refugees. All three priorities with the implementation strategy can be used as a solution in the response to the Community nutrition disaster victims, especially in vulnerable groups i.e: infants, toddlers, children, pregnant women, nursing mothers, and the elderly.

\section{ACKNOWLEDGMENT}

This research was supported by Universitas Negeri Padang (UNP) and Pagar Alam City Goverment. We also thank of Chairman of Postgraduate UNP and Students involved in research for their support in this research.

\section{REFERENCES}

1. D. Hermon, Mitigation and Adaptation: Disaster of Climate Change. Sara Book Publication. India, 2019

2. Hermon, D., Putra, A and Oktorie, O. Suitability Evaluation of Space Utilization Based on Enviromental Sustainability at The Coastal Area of Bungus Bay in Padang City, Indonesia. International Journal, Vol.14, No.41, pp. 193-202. 2018

3. D. Hermon, Evaluation of physical development of the coastal tourism regions on tsunami potentially zones in Pariaman City-Indonesia. International Journal of GEOMATE, Vol. 17, Issue. 59, pp.189-196, 2019.

4. Hermon, D., Ganefri, Erianjoni, I. Dewata, P. Iskarni and A. Syam, A Policy Model of Adaptation Mitigation and Social Risks The Volcano Eruption Disaster of Sinabung in Karo Regency-Indonesia. International Journal of GEOMATE, Vol.17, No.60, pp190-196. 2019

5. Arlym, L., D. Hermon, D. Lanin, O. Oktorie and A. Putra. A Policy Model of Preparedness The General Hospital in Reducing Victims of Earthquake and Tsunami Disasters in Siberut Mentawai Island, Indonesia. International Journal of Recent Technology and Engineering (IJRTE). Vol. 8. Issue 3. 2019 
6. A. Zaennudin, The characteristic of eruption of Indonesian active volcanoes in the last four decades. Jurnal Lingkungan dan Bencana Geologi, Vol. 1, Issue. 2, pp.113-129, 2010

7. J.T. van Gorsel, South Sumatra and Bengkulu-17th Annual Post-Convention Field Trip, 1988

8. A. Bertagnini and Principe, C, A review on phreatic eruptions and their precursors. Journal of volcanology and geothermal research, Vol. 52, pp.231-246, 1992

9. United Nations High Commissioner for Refugees (UNHCR), Handbook for emergencies. United Nations High Commissioner for Refugees.2007

10. A.A. Cronin, D. Shrestha, N. Cornier, F. Abdalla, N. Ezard and C. Aramburu, C, A review of water and sanitation provision in refugee camps in association with selected health and nutrition indicators-the need for integrated service provision. Journal of water and health, Vol. 6, Issue. 1, pp. 1-13, 2008

11. J.L. Gamble, J. Balbus, M. Berger, K. Bouye, V. Campbell, K. Chief and E. Hallisey, Ch. 9: Populations of concern (pp. 247-286). US Global Change Research Program, Washington, DC. 2016

12. S.M. Alraga, An Investigation into Disaster Health Managemen $t$ in Saudi Arabia. J Hosp Med Manage, Vol.3, Issue. 2, pp.18, 2017

13. I. Basak and T. Saaty, (1993). Group decision making using the analytic hierarchy process. Mathematical and computer modelling, Vol.17, Issue. 4-5, pp.101-109.

14. L. Ismaini, M. Lailati, R. Rustandi and D. Sunandar, Composition and plant diversity analysis on Mount Dempo, South Sumatra. In Prosiding Seminar Nasional Masyarakat Biodiversitas Indonesia, Vol. 1, No. 6 , pp. 1397-1402, 2015.

15. L.S. Stephenson, M.C. Latham and E.A. Ottesen, Malnutrition and parasitic helminth infections. Parasitology, Vol.121, Issue. S1, pp.S23-S38. 2000

16. C.B. Clement and R.C. Asmundson, Nutritional intake and hematological parameters in endurance runners. The Physician and sportsmedicine, Vol.10, Issue. 3, pp. 37-43, 1982

17. E.S. Wirakusumah, Menu Sehat Untuk Lanjut Usia. Cet. 1. Jakarta: Puspa Swarsa, 2001.

18. S. Salmayati, H. Hermansyah and A. Agussabti, Kajian penanganan gizi balita pada kondisi kedaruratan bencana banjir di kecamatan sampoiniet kabupaten aceh jaya', Jurnal Kedokteran Syiah Kuala, Vol. 16, Issue. 3, pp. 176-180. 2016

19. R.B.K Anandito, S. Siswanti, E. Nurhartadi and R. Hapsari, Formulasi Pangan Darurat Berbentuk Food Bars Berbasis Tepung Millet Putih (Panicum milliaceum L.) dan Tepung Kacang Merah (Phaseolus vulgaris L.). Agritech, Vol.36, Issue. 1, pp.23-29, 2016

20. M. Hermayanti, N.L. Rahmah and S.Wijana, (2016). Formulasi Biskuit Sebagai Produk Alternatif Pangan Darurat. Industria: Jurnal Teknologi dan Manajemen Agroindustri, Vol.5, Issue. 2, pp.107-113

21. I. Kusumastuty, L. Fandianty and A.R. Julia, Formulasi food bar tepung bekatul dan tepung jagung sebagai Pangan darurat. Indonesian journal of human nutrition, Vol.2, Issue. 2, pp.68-75. 2015

22. T. Sunyoto, J. Potet and M. Boelaert, Why miltefosine-a life-saving drug for leishmaniasis - is unavailable to people who need it the most. BMJ global health, Vol. 3, Issue. 3, pp.e000709, 2018.

\section{AUTHORS PROFILE}

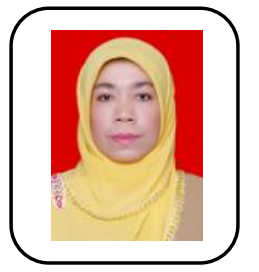

Yessy Aprihatin is a Research, Nurse and Lecturer of Diploma III Nursing, Universitas Neger Padang, obtained the Master Degree in Health Management at STIE Indonesia Malang. He is actively involved in any researches regarded to environmental health and produces several scientific works in the form of SINTA-Indonesia indexed journals (ID: 6698607). Right now he is a student Doctoral Program of Environmental Science, Universitas Negeri Padang and as head Laboratorium of maternity, child, community, and soul on Program of Diploma III Nursing the Universitas Negeri Padang the period 2019-2023.

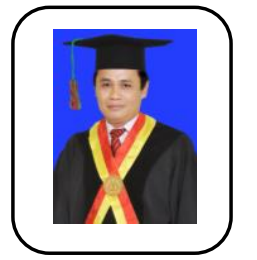

Dedi Hermon is a Professor of Disaster Geography, obtained the Doctorate Degree in Doctor Program Natural Resources Management and Environment at Bogor Agriculture University, 2009. $\mathrm{He}$ is actively involved in any researches regarded to natural disaster, land cover, carbon stock and produces several scientific works in the form of Scopus indexed journals (ID: 57200409691) and scientific books both national and international publications. He is assistant director of Postgraduate Universitas Negeri Padang as well as the head of Study Center of Disaster and Environment, Universitas Negeri Padang.

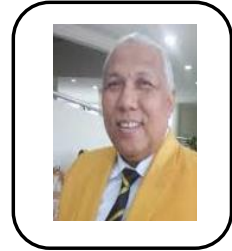

Eri Barlian is a Professor of Environmenta Education, obtained the Doctorate Degree in Doctor Program Education Science at Universitas Negeri Jakarta, 1999. He is actively involved in any researches regarded to environmental education, sports, recreation and disaster and produces severa scientific works in the form of Scopus indexed journals (ID: 57202293479). He is Chair of Doctoral Program of Environmental Science, Universitas Negeri Padang.

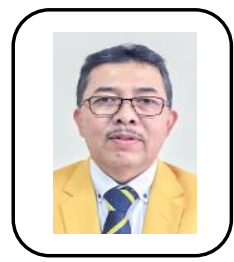

Indang Dewata is an Associate professor of Environmental Science, obtained the Doctorate Degree in Doctor Program Education Science at Universitas Indonesia, 2009. He is actively involved in any researches regarded to environmental science, chemical and produces several scientific works in the form of Scopus indexed journals (ID: 57202287960). $\mathrm{He}$ is Chair of Masters Program of Environmental Science, Universitas Negeri Padang.

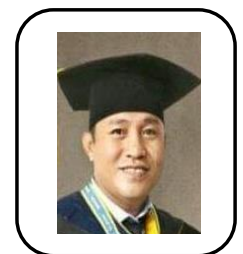

Iswandi Umar is an Associate professor of Environmental Science, obtained the Doctorate Degree in Doctor Program Natural Resources Management and Environment at Bogor Agriculture University, 2015. He is actively involved in any researches regarded to environmental science, geography and produces several scientific works in the form of Scopus indexed journals (ID: 57204825796). He is Chair of Masters Program of Geography Education, Universitas Negeri Padang.

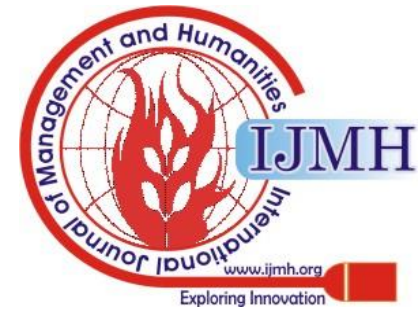

